\title{
Pumping Problem
}

National Cancer Institute

\section{Source}

National Cancer Institute. Pumping Problem. NCI Thesaurus. Code C62860.

Problem associated with pump performance deviating from specifications in a way to compromise flow or infusion. 